\title{
Energy value of babassu cake as substitute bulk in sheep diets
}

\section{Valor energético da torta de babaçu em substituição ao volumoso na alimentação de ovinos}

\author{
Kélvia Jácome de Castro'; Silas Primola Gomes²; Iran Borges; Fabrícia Rocha \\ Chaves Miotto ${ }^{4}$; Patrícia Guimarães Pimentel ${ }^{5 *}$; Andréa Pereira Pinto5; \\ Guilherme Rocha Moreira6; José Neuman Miranda Neiva ${ }^{4}$
}

\section{Highlights}

Babassu cake can replace up to $350 \mathrm{~g} \mathrm{~kg}^{-1}$ Tifton-85 hay dry matter in the diet. Babassu cake increased the energy efficiency of the diet.

The addition of babassu cake to the diet helped to reduce methane production.

\begin{abstract}
The aim of this study was to evaluate the energy value of diets containing babassu cake as a replacement for Tifton-85 hay $\left(70,140,210,280\right.$ and $350 \mathrm{~g} \mathrm{~kg}^{-1}$ dry matter, DM), using the technique of indirect calorimetry. Twenty-five castrated male Santa Inês sheep, with an average body weight of $49.6+9.4 \mathrm{~kg}$, were used in a completely randomised design. The trial was carried out in an individual open-flow respirometry chamber for small ruminants, with each animal remaining for 24 hours inside the chamber. Gross energy and net energy intake were not affected by adding the cake. Digestible energy intake and metabolisable energy intake showed a linear response, ranging from 145.44 to 178.40 and from 121.85 to $158.08 \mathrm{kcal}^{\mathrm{kg}^{-0.75}}$ day $^{-1}$ respectively. The energy lost through faeces and methane (\% of gross energy intake, GEI) showed decreasing linear behaviour, while the caloric increase, in \%GEl, showed a quadratic response. The values for digestible energy and metabolisability presented an increasing linear response. The partial efficiency of

1 Profa Dra of the Federal Institute of Education, Science and Technology of Ceará, IFCE, Tauá, CE, Brazil. E-mail: kelvia.jacome@ifce.edu.br

2 Prof. Dr. of Rural Development Institute, University of International Integration of Afro-Brazilian Lusophony, UNILAB, Redenção, CE, Brazil. E-mail: silas.primola@unilab.edu.br

${ }^{3}$ Retired Prof. Dr. of Animal Science Department of Veterinary School, Federal University of Minas Gerais, UFMG, Belo Horizonte, MG, Brazil. E-mail: borgeszootec@gmail.com

${ }^{4}$ Profs. Drs. of Veterinary Medicine and Animal Science School, Federal University of Tocantins, UFT, Araguaína, TO, Brazil. E-mail: fabriciarchaves@uft.edu.br; araguaia2007@gmail.com

${ }^{5}$ Profas Dras of Animal Science Department, Federal University of Ceará, UFC, Fortaleza, CE, Brazil. E-mail: pgpimentel@hotmail.com; deiapp@hotmail.com

6 Prof. Dr. of Statistic and Informatic Department, Federal Rural University of Pernambuco, UFRPE, Recife, PE, Brazil. E-mail: guirocham@gmail.com

* Author for correspondence
\end{abstract}

Received: Nov. 22, 2020 - Approved: Mar. 15, 2021 
use of metabolisable energy for maintenance ranged from 0.71 to 0.81 , and showed a quadratic response; however, the net energy values did not differ. For every $10 \mathrm{~g}$ of added by-product, there was a reduction of $0.31 \mathrm{~g}$ of methane per $\mathrm{kg}$ of DM intake. The addition of babassu cake to replace up to $350 \mathrm{~g} \mathrm{~kg}^{-1} \mathrm{DM}$ in sheep diets increases the energy efficiency of the diet and reduces methane emission by the animals.

Key words: Indirect calorimetry. Energy metabolism. Methane. Agro-industrial by-product.

\section{Resumo}

Objetivou-se avaliar o valor energético de rações contendo torta de babaçu em substituição ao feno de Tifton-85 (70; 140; 210; 280 e $350 \mathrm{~g} \mathrm{~kg}^{-1}$ de matéria seca, MS), pela técnica da calorimetria indireta. Foram utilizados 25 ovinos da raça Santa Inês, machos castrados, com peso corporal médio de 49,6 + 9,4 kg, em delineamento inteiramente casualizado. $\mathrm{O}$ ensaio experimental foi realizado em câmara respirométrica individual de fluxo aberto para pequenos ruminantes, permanecendo cada animal por período de 24 horas no interior da câmara. Os consumos de energia bruta e energia líquida não foram influenciados pela inclusão da torta. Os consumos de energia digestível e energia metabolizável apresentaram resposta linear, variando de 145,44 a 178,40 e de 121,85 a 158,08 kcal kg pelas fezes e pelo metano (\% do consumo da energia bruta, CEB) apresentaram comportamento linear decrescente, enquanto o incremento calórico, em \%CEB, apresentou resposta quadrática. Os valores de energia digestível e metabolizabilidade apresentaram respostas lineares crescentes. A eficiência parcial de uso da energia metabolizável para mantença variou entre 0,71 a 0,81, com resposta quadrática, porém os valores de energia líquida não diferiram. Para cada $10 \mathrm{~g}$ de inclusão de subproduto, houve redução de 0,31 g de metano por kg de MS consumida. A inclusão de torta de babaçu, em substituição ao volumoso, na ração de ovinos, em até $350 \mathrm{~g} \mathrm{~kg}^{-1} \mathrm{MS}$, aumenta a eficiência energética da ração e reduz a emissão de metano pelos animais.

Palavras-chave: Calorimetria indireta. Metabolismo energético. Metano. Subproduto agroindustrial.

\section{Introduction}

In the north and northeast of Brazil, babassu (Orbygnia sp.) is one of the main plants used as a source of raw material for the production of biofuel, generating a considerable number of by-products, including babassu cake (Carrera et al., 2012).

The use of babassu cake in ruminant diets is widespread, especially among producers in the north and northeast of Brazil. However, little is known about the nutritional value of this feed, and most studies of babassu cake are limited to assessing intake, performance and apparent digestibility (Carrera et al., 2012; Freitas, Siqueira, \& Siqueira, 2014). No information on the characterisation of energy partitioning in diets containing this feed, nor on the methane production of animals fed with babassu cake, was found in the literature.

The energy content of the diet is one of the main determinants of animal production, and knowledge of the energy efficiency of diets is essential (López \& Fernández, 2013). The energy generated by the oxidation of nutrients in the organism of the animal can be used to maintain vital processes or to carry out work (Machado et al., 2015). The gross energy content of the diet should not be 
used to balance the diet, due to variations in digestibility and metabolism. Therefore, the most accurate way to formulate ruminant diets is using the net energy content; however, if this is not possible, the metabolisable energy can also be used.

The energy retained in body tissue or used in production is calculated as the difference between the total gross energy intake and the energy lost through faeces, urine and gases, and in heat production (Machado et al., 2015). Methane production by ruminants is directly related to the efficiency of use of the digestible energy (Ribeiro et al., 2015), and because it is an important greenhouse gas (Grainger \& Beauchemin, 2011; Tangjitwattanachai, Phaowphaisal, \& Sommart, 2015), studies that determine methane emission by ruminants are extremely important, and aid in the adoption of managements that improve the efficiency of use of the diet.

With the use of respirometry chambers, it is possible to estimate the net energy content, since the production of methane and heat can be quantified. Therefore, the aim of this study was to determine the energy value and the effects of adding babassu cake as a substitute bulk in sheep diets on energy metabolism and methane production, using the technique of indirect calorimetry.

\section{Material and Methods}

The trial was carried out in an individual open-flow respirometry chamber for small ruminants at the Animal Metabolism and Calorimetry Laboratory (LAMCA), and the laboratory analyses were carried out at the Animal Nutrition Laboratory, both located at the Veterinary School of the Federal University of Minas Gerais (UFMG).

Twenty-five castrated male Santa Inês sheep were used, with an average body weight of $49.6+9.4 \mathrm{~kg}$ and approximate age of 18 months. The animals were first sheared, weighed, identified, dewormed, given an ADE vitamin complex, and then individually housed in metabolic cages. A completely randomised design was used, with five levels of babassu cake added to the diets to replace the Tifton-85 hay $\left(70,140,210,280\right.$ and $\left.350 \mathrm{~g} \mathrm{~kg}^{-1} \mathrm{DM}\right)$ and five replications. The experimental diets were offered once a day, at 07:00. The babassu cake was obtained through the mechanical extraction of almond oil.

Each animal remained for 24 hours inside the respirometry chamber. Inside the chamber, the animals were housed in a metabolic cage to allow feed intake to be assessed by collecting the leftovers, as well as the urine and faeces. To avoid excess ammonia inside the chamber, $100 \mathrm{~mL}$ of $\mathrm{HCl}_{2} \mathrm{~N}$ was added to the urine collection bucket. Next to the respirometry chamber was a second chamber where a metabolic cage housing another animal was placed with the aim of adapting the animals to the chamber environment.

The samples of food, leftovers and faeces were pre-dried in a forced ventilation oven at $55^{\circ} \mathrm{C}$ for 72 hours and then ground in a Wiley mill with a 1-mm sieve, packed in plastic pots and stored for later analysis.

The ingredients and concentrated diets at the various levels of addition were analysed for dry matter (DM), crude protein (CP), mineral matter (MM), ether extract (EE), neutral detergent fibre (NDF) and acid detergent fibre (ADF), as per the methodology described by 
Silva and Queiroz (2002). To estimate total and non-fibrous carbohydrates, the equations proposed by Sniffen, O'Connor, Van Soest, Fox and Russell (1992) were adopted (Tables 1 and 2). Urine samples from the fed animals were analysed to determine gross energy and total nitrogen. However, urine samples from fasting animals were analysed to determine total nitrogen only.

Table 1

Chemical composition of the ingredients of the experimental diets

\begin{tabular}{|cccc|}
\hline \multirow{2}{*}{ Item } & \multicolumn{3}{c|}{ Ingredients } \\
\cline { 2 - 4 } Dry matter $^{1}$ & Babassu cake & Ground maize & Tifton-85 hay \\
\hline Mineral matter $^{2}$ & 901.0 & 849.8 & 858.8 \\
\hline Crude protein $^{2}$ & 44.9 & 30.0 & 64.3 \\
\hline Ether extract $^{2}$ & 205.8 & 105.8 & 84.8 \\
\hline Neutral detergent fibre $^{2}$ & 94.2 & 41.0 & 11.0 \\
\hline Acid detergent fibre $^{2}$ & 630.6 & 136.3 & 778.6 \\
\hline Hemicellulose $^{2}$ & 340.0 & 37.4 & 391.4 \\
\hline Total carbohydrates $^{2}$ & 290.6 & 98.9 & 387.2 \\
\hline Non-fibrous carbohydrates $^{2}$ & 655.1 & 823.2 & 839.9 \\
\hline Gross energy $^{3}$ & 24.5 & 686.9 & 61.3 \\
\hline
\end{tabular}

${ }^{1} \mathrm{~g} \mathrm{~kg}^{-1}$ natural matter; ${ }^{2} \mathrm{~g} \mathrm{~kg}^{-1} \mathrm{dry}$ matter; ${ }^{3} \mathrm{kcal} \mathrm{g}^{-1}$ dry matter.

The respirometry test was carried out in two phases. First, gas exchange and heat production (HP) was calculated in the fed animals. During this stage, the animals received the diet once a day, every morning before the chamber was closed. The supply was adjusted to provide intake at the maintenance level (from 50 to $80 \mathrm{~g}$ dry matter per kilogram of unit of metabolic size; $\mathrm{g} \mathrm{DM} \mathrm{kg}^{-0.75}$ ), and checked by periodically weighing the animals. The leftovers were collected and weighed the following day as soon as the chamber was opened, and intake was calculated by subtraction. In addition to the diet, the animals received water and mineral mixture ad libitum. 
Table 2

Composition of experimental diets containing babassu cake as a substitute for Tifton- 85 hay

\begin{tabular}{|c|c|c|c|c|c|}
\hline \multirow{2}{*}{ Ingredient (g kg-1 DM) } & \multicolumn{5}{|c|}{ Level of substitution ( $\mathrm{g} \mathrm{kg}^{-1} \mathrm{DM}$ ) } \\
\hline & 70.0 & 140.0 & 210.0 & 280.0 & 350.0 \\
\hline Babassu cake & 70.0 & 140.0 & 210.0 & 280.0 & 350.0 \\
\hline Ground maize & 30.0 & 60.0 & 90.0 & 120.0 & 150.0 \\
\hline Tifton-85 hay & 900.0 & 800.0 & 700.0 & 600.0 & 500.0 \\
\hline Item & \multicolumn{5}{|c|}{ Chemical composition } \\
\hline Dry matter ${ }^{1}$ & 861.2 & 863.5 & 865.8 & 868.1 & 870.5 \\
\hline Mineral matter ${ }^{2}$ & 62.6 & 60.9 & 59.2 & 57.5 & 55.9 \\
\hline Crude protein ${ }^{2}$ & 94.9 & 105.1 & 115.2 & 125.3 & 135.5 \\
\hline Ether extract ${ }^{2}$ & 17.7 & 24.4 & 31.2 & 37.9 & 44.6 \\
\hline Neutral detergent fibre ${ }^{2}$ & 750.4 & 722.1 & 693.9 & 665.6 & 637.4 \\
\hline Acid detergent fibre ${ }^{2}$ & 375.8 & 360.2 & 344.6 & 329.0 & 313.4 \\
\hline Hemicellulose ${ }^{2}$ & 374.6 & 361.9 & 349.3 & 336.6 & 324.0 \\
\hline Total carbohydrates ${ }^{2}$ & 824.8 & 809.6 & 794.4 & 779.3 & 764.1 \\
\hline Non-fibrous carbohydrates ${ }^{2}$ & 74.4 & 87.5 & 100.6 & 113.7 & 126.7 \\
\hline Gross energy ${ }^{3}$ & $4,395.6$ & $4,440.6$ & $4,485.6$ & $4,530.5$ & $4,575.5$ \\
\hline
\end{tabular}

${ }^{1} \mathrm{~g} \mathrm{~kg}^{-1}$ natural matter; ${ }^{2} \mathrm{~g} \mathrm{~kg}^{-1}$ dry matter; ${ }^{3} \mathrm{kcal} \mathrm{g}{ }^{-1}$ dry matter.

During the second phase, heat production was calculated in seven fasting sheep. The average for HP of these animals was used to calculate the caloric increase of the other animals. Before entering the chamber, the animals were fasted for 48 hours to empty the entire gastrointestinal tract. The animals then remained inside the respirometry chamber for 24 hours, receiving only water. Once the chamber was opened, the volume of excreted urine was measured, and a $100 \mathrm{~mL}$ aliquot was taken for nitrogen $(\mathrm{N})$ analysis.

The method described by Rodriguez et al. (2007) was used in the indirect calorimetry procedure. Aliquots of the air, both inside and outside the chamber, were collected alternately every five minutes to determine the levels of oxygen $\left(\mathrm{O}_{2}\right)$, carbon dioxide $\left(\mathrm{CO}_{2}\right)$ and methane $\left(\mathrm{CH}_{4}\right)$. Inside the chamber, the temperature and humidity were controlled by air conditioning, and recorded during the first and last reading.

The respiratory coefficient (RC) was calculated from the ratio between the $\mathrm{CO}_{2}$ production (L) and the $\mathrm{O}_{2}$ intake (L). Heat production was calculated as per the equation described by Rodriguez et al. (2007):

$$
\begin{gathered}
\mathrm{HP}=16.18 \times \mathrm{O}_{2}+5.02 \times \mathrm{CO}_{2}-2.17 \times \mathrm{CH}_{4}- \\
5.99 \times \mathrm{UN}
\end{gathered}
$$

where: $\mathrm{HP}=$ heat production $(\mathrm{kJ}) ; \mathrm{O}_{2}(\mathrm{~L}) ; \mathrm{CO}_{2}$ $(\mathrm{L}) ; \mathrm{CH}_{4}(\mathrm{~L})$ and $\mathrm{UN}=$ urine nitrogen $(\mathrm{g})$.

In transforming the data into calories, the value of 1 joule corresponding to 0.239 calories was taken as reference. The values for digestible energy (DE) were obtained from the difference between the GEI (energy supplied minus energy from the leftovers) and the GE excreted in the faeces. 
Metabolisable energy (ME) was calculated from the difference between the $\mathrm{DE}$ and the energy lost in the form of methane and urine. An energy value for $\mathrm{CH}_{4}$ of $9.44 \mathrm{kcal}$ $\mathrm{L}^{-1}$ was adopted as per Blaxter and Clapperton (1965).

The values for net energy (NE) were calculated from the difference between the $\mathrm{ME}$ and the energy lost to caloric increase.

To calculate the caloric increase, the mean value for heat production in the fasting animals was subtracted from the values for heat production in the fed animals:

$$
\mathrm{Cl}=\mathrm{PCfe}-\mathrm{PCfa}
$$

where: $\mathrm{Cl}=$ caloric increase; $\mathrm{HPfe}=$ heat production in the fed animal; and $\mathrm{HPfa}=$ heat production in the fasting animal.

To calculate the energy lost in the form of methane in grams per day $\left(\mathrm{g} \mathrm{day}^{-1}\right)$, grams per kilogram of ingested dry matter $\left(\mathrm{g} \mathrm{kg}^{-1}\right.$ DM), and kilocalories per kilogram of ingested dry matter (kcal kg-1 DM), a value of $13.334 \mathrm{kcal}$ $\mathrm{g}^{-1}$ and density of $0.7143 \mathrm{~g} \mathrm{~L}^{-1}$ was considered (Machado et al., 2015).

To determine the $\mathrm{DE}$, the gross energy intake and faecal gross energy production were used:

$$
\mathrm{DE}=\mathrm{GE} \text { consumed }-\mathrm{GE} \text { faecal }
$$

The values for the metabolisability of the gross energy $\left(q_{m}\right)$ were obtained as per the Agricultural and Food Research Council [AFRC] (1993), with the following formula:

$$
\mathrm{qm}=(\mathrm{MEI} \times 100) / \mathrm{GEI}
$$

where: $\mathrm{MEI}=$ metabolisable energy intake (kcal day $\left.^{-1}\right) ; \mathrm{GEI}=$ gross energy intake (kcal day $\left.{ }^{-1}\right)$.

The efficiency of use of metabolisable energy (km), obtained as per AFRC (1993), was calculated using the formula:

$$
\mathrm{km}=(\mathrm{NE} \times 100) / \mathrm{ME}
$$

where: $\mathrm{NE}=$ net energy content $\left(\mathrm{kcal} \mathrm{kg}^{-1} \mathrm{DM}\right)$; $\mathrm{ME}=$ metabolisable energy content $\left(\mathrm{kcal} \mathrm{kg}^{-1}\right.$ DM).

The data obtained in the respirometry test were adjusted for the consumption seen in the test for apparent digestibility. This adjustment was necessary, since the intake seen in the respirometry test was different from that seen in the test for digestibility. In addition, in calculating energy partitioning, the GE content was determined in the samples of leftovers, faeces and urine collected during the first experiment.

The assumptions of normal distribution and homoscedasticity were verified from the data. Regression analysis was then carried out, the most appropriate model for each variable being chosen based on the significance of the linear and quadratic coefficients, using a level of 0.05 . The SAS statistical software was used (SAS Institute, v 9.1).

\section{Results and Discussion}

Neither gross energy (GEI) nor net energy (NEI) intake was affected by the diets $(\mathrm{P}>0.05)$ (Table 3). According to Machado et al. (2015), GEI has a high correlation with dry matter intake (DMI) in $\mathrm{kg} \mathrm{DM} \mathrm{kg}^{-0.75}$ (DMI x GEI $=0.997)(P<0.0001)$. Studying the nutritional value of diets with increased added babassu cake, no effect was found on the DMI of the animals $\left(\tilde{Y}=63.79+9.37 \mathrm{~g} \mathrm{~kg}^{-0.75}\right)(P>0.05)$, which partially explains the GEI not being affected, since the levels of GE in the diets did not vary. For GEl, the values ranged from 241.08 to $287.65 \mathrm{kcal} \mathrm{kg}^{-0.75}$ day $^{-1}$, with an average of $261.26+19.41 \mathrm{kcal} \mathrm{kg}^{-0.75}$ day $^{-1}$. 
Table 3

Gross energy intake (GEI), digestible energy intake (DEI), metabolisable energy intake (MEI) and net energy intake (NEI), in sheep fed babassu cake as a substitute for Tifton-85 hay

\begin{tabular}{|c|c|c|c|c|c|c|c|c|}
\hline \multirow{2}{*}{ Variable } & \multicolumn{5}{|c|}{ Level of substitution ( $\mathrm{g} \mathrm{kg}^{-1} \mathrm{DM}$ ) } & \multirow{2}{*}{ Equation } & \multirow{2}{*}{$r^{2}$} & \multirow{2}{*}{ CV (\%) } \\
\hline & 70 & 140 & 210 & 280 & 350 & & & \\
\hline $\mathrm{GEI}^{1}$ & 243.10 & 241.08 & 266.26 & 287.65 & 268.21 & $Y=261.26+19.41^{\mathrm{ns}}$ & - & 14.89 \\
\hline $\mathrm{DEI}^{1}$ & 145.56 & 145.44 & 166.81 & 178.40 & 171.63 & $\hat{Y}=136.04+0.122 X^{*}$ & 0.78 & 16.30 \\
\hline $\mathrm{MEI}^{1}$ & 121.85 & 123.30 & 143.20 & 158.08 & 152.57 & $\hat{Y}=110.93+0.137 X^{*}$ & 0.84 & 19.42 \\
\hline $\mathrm{NEI}^{1}$ & 86.71 & 101.81 & 110.72 & 128.73 & 109.05 & $Y=107.40+15.23^{n s}$ & - & 23.75 \\
\hline
\end{tabular}

${ }^{1} \mathrm{kcal}$ per unit of metabolic size $\left(\mathrm{kg}^{-0.75} \mathrm{kcal}\right)$ per day; ${ }^{*}=\mathrm{P}<0.05 ;{ }^{\mathrm{ns}}=\mathrm{P}>0.05$.

Miotto, Restle, Neiva, Maciel and Fernandes (2012), evaluating increasing levels of babassu mesocarp bran added to sheep diets to replace elephant grass silage, also found no effect on dry matter intake or total digestible nutrient intake (TDNI) when measured in $\mathrm{g} \mathrm{day}^{-1}$. Gomes et al. (2012), evaluating the effect of feeding frequency and particle size in diets based on Tifton-85 hay and commercial concentrate (bulk to concentrate ratio of 25:75) on energy metabolism in sheep, found a mean GEl of $285.1 \mathrm{kcal} \mathrm{kg}^{-0.75}$ day $^{-1}$.

The NEl showed an average of 107.40 $+15.23 \mathrm{kcal} \mathrm{kg}^{-0.75}$ day $^{-1}$ and, despite having varied between 86.71 and $128.73 \mathrm{kcal} \mathrm{kg}^{-0.75}$, showed no difference ( $P>0.05)$. The values for NEl were higher than those reported by Machado et al. (2015), who studied the silage from three sorghum hybrids and found $\mathrm{NEI}$ values ranging from 47.68 to $96.17 \mathrm{kcal} \mathrm{kg}^{-0.75}$ day $^{-1}$, lower than that reported by Gomes et al. (2012) for diets containing Tifton-85 hay (Cynodon spp.), of $118.9 \mathrm{kcal} \mathrm{kg}^{-0.75}$ day $^{-1}$.

The digestible energy intake (DEI) showed increasing linear behaviour $(P<0.05)$ in response to the addition of babassu cake to the diets. For each $10 \mathrm{~g}$ of cake included in the diet, there was an increase in DEI of $1.22 \mathrm{kcal}$ $\mathrm{kg}^{-0.75}$ day $^{-1}$. The values ranged from 145.44 to $178.40 \mathrm{kcal} \mathrm{kg}^{-0.75}$ day $^{-1}$. Gomes et al. (2012) found a mean value for DEI of $281.56 \mathrm{kcal} \mathrm{kg}^{-0.75}$ day $^{-1}$ in diets containing a high proportion of concentrate $(75 \%)$.

Similarly, increasing linear behaviour $(P<0.05)$ was seen in the values for metabolisable energy intake (MEl), with an increase of $1.37 \mathrm{kcal} \mathrm{kg}^{-0.75}$ day $^{-1}$ for every 10 $\mathrm{g}$ increase in babassu cake, the values ranging from 121.85 to $158.08 \mathrm{kcal} \mathrm{kg}^{-0.75} \mathrm{day}^{-1}$. These values were higher than those reported by Machado et al. (2015) in the silage of sorghum hybrids, that varied from 89.38 to $125.46 \mathrm{kcal}$ $\mathrm{kg}^{-0.75}$ day $^{-1}$.

The increase in DEl and MEl leads to the conclusion that adding babassu cake as a substitute for Tifton-85 hay increases the use of dietary energy in the gastrointestinal tract, resulting in greater efficiency for these diets. From the regression equation for $\mathrm{MEl}$, an $\mathrm{ME}$ value of $3.26 \mathrm{Mcal} \mathrm{kg}^{-1} \mathrm{DM}$ was found for the babassu cake.

Regarding the energy lost through faeces in kcal $\mathrm{kg}^{-0.75}$ day $^{-1}$, there was no difference between the diets under evaluation 
$(P>0.05)$, with a mean value of $99.69+5.53 \mathrm{kcal}$ $\mathrm{kg}^{-0.75}$ day $^{-1}$ (Table 4). However, the energy lost through faeces in \%GEl showed decreasing linear behaviour $(P<0.05)$; for every additional $10 \mathrm{~g}$ of babassu cake in the diet, the faecal loss of energy in relation to GE intake was reduced by $0.15 \%$.
According to Machado et al. (2015), faecal losses can represent 48 to $52 \%$ of the energy intake, and is the main form of energy loss, followed by caloric increase (10 to $19 \%$ ), methane emission ( 4 to $5 \%$ ) and urine (1 to $2 \%)$. It is therefore of the utmost importance to maximise diet digestibility and minimise caloric increase as a way of increasing feed efficiency.

Table 4

Daily energy losses through faeces and urine, the loss of methane $\left(\mathrm{CH}_{4}\right)$ and caloric increase $(\mathrm{Cl})$, in sheep fed babassu cake as a substitute for Tifton- 85 hay

\begin{tabular}{|c|c|c|c|c|c|c|c|c|}
\hline \multirow{2}{*}{ Variable } & \multicolumn{5}{|c|}{ Level of substitution ( $\left.\mathrm{g} \mathrm{kg}^{-1} \mathrm{DM}\right)$} & \multirow{2}{*}{ Equation } & \multirow{2}{*}{$r^{2}$} & \multirow{2}{*}{ CV (\%) } \\
\hline & 70 & 140 & 210 & 280 & 350 & & & \\
\hline Faeces $^{1}$ & 97.55 & 95.63 & 99.45 & 109.26 & 96.58 & $Y=99.69+5.53^{\text {ns }}$ & - & 16.00 \\
\hline Faeces $^{2}$ & 40.06 & 40.31 & 37.19 & 38.03 & 36.01 & $\hat{Y}=41.43-0.015 X^{*}$ & 0.79 & 8.17 \\
\hline Urine $^{1}$ & 3.46 & 5.66 & 4.82 & 6.19 & 4.55 & $Y=4.94+1.05^{\mathrm{ns}}$ & - & 35.20 \\
\hline Urine $^{2}$ & 1.41 & 2.71 & 1.84 & 2.17 & 1.71 & $Y=1.97+0.50^{\text {ns }}$ & - & 54.69 \\
\hline $\mathrm{CH}_{4}{ }^{1}$ & 20.25 & 16.51 & 18.69 & 14.29 & 14.57 & $Y=16.86+2.59^{\text {ns }}$ & - & 31.83 \\
\hline $\mathrm{CH}_{4}{ }^{2}$ & 8.29 & 7.16 & 7.33 & 5.02 & 5.49 & $\hat{Y}=8.98-0.011 X^{*}$ & 0.81 & 35.66 \\
\hline $\mathrm{Cl}^{1}$ & 35.14 & 21.49 & 32.48 & 29.35 & 43.52 & $Y=32.39+8.05^{n s}$ & - & 37.12 \\
\hline $\mathrm{Cl}^{2}$ & 14.76 & 9.27 & 11.64 & 10.43 & 16.10 & $\hat{Y}=20.66-0.109 X+0.0003 X^{2 *}$ & 0.79 & 36.22 \\
\hline
\end{tabular}

${ }^{1} \mathrm{kcal}$ per unit of metabolic size $\left(\mathrm{kcal} \mathrm{kg}^{-0.75}\right)$ per day; ${ }^{2}$ gross energy intake $(\% \mathrm{GEI}){ }^{*}=\mathrm{P}<0.05 ;{ }^{\mathrm{ns}}=\mathrm{P}>0.05$.

Energy losses, whether through faeces or in other forms, are mainly associated with the chemical composition of the diet, where smaller losses are related to high concentrations of non-fibrous carbohydrates (NFC), while greater losses are related to the presence of large amounts of fibrous carbohydrates (Knapp, Laur, Vadas, Weiss, \& Tricarico, 2014). As such, the reduction in fibrous carbohydrate content (NDF and ADF) and the consequent increase in NFC content from the increase in babassu cake added to the diet (Table 2), may explain the reduction in faecal energy loss when expressed as a percentage of GE intake.
Adding babassu cake to the diets did not affect the energy lost through urine $(P>0.05)$, whether expressed in kcal kg-0.75 day $^{-1}$ or as a percentage of GE intake. The mean value for the energy lost through urine was $4.94+1.05 \mathrm{kcal} \mathrm{kg}^{-0.75}$ day $^{-1}$, equal to $1.97 \%$ of GE intake. According to the National Research Council [NRC] (2007), energy lost through urine corresponds to $4 \%$ to $5 \%$ of GE intake, a value almost three times higher than that seen here. However, it should be noted that the coefficients of variation for energy loss can be considered high for animal experimentation. 
In ruminants, in addition to the energy lost through faeces and urine, energy is also lost through the production of methane and heat. According to the NRC (2007), energy loss in the form of methane is between $5 \%$ to $8 \%$ of GE intake, values close to those reported by Machado et al. (2015), of $4 \%$ to $5 \%$. In the present study, the loss of methane, expressed as $\mathrm{kcal} \mathrm{kg}^{-0.75}$ day $^{-1}$, was not affected by the experimental diets $(P>0.05)$; however, when expressed as a percentage of GE intake, the loss of methane showed a decreasing linear response $(P<0.05)$, where the values ranged from $5.02 \%$ to $8.29 \%$, higher than those found in the literature, with the highest values found in diets with less added babassu cake and, consequently, with a higher bulk content.

Methane production is related to the final products obtained from the fermentation of carbohydrates. Therefore, a diet with high added concentrate of a lower acetate to propionate molar ratio will produce less methane than a diet with a higher proportion of forage and a higher acetate to propionate molar ratio (Tangjitwattanachai et.al., 2015). This shows there is an inverse relationship between the production of propionate and methane (Knapp et al., 2014); in addition, the type of forage ingested will also influence methane production. Meale, Chaves, Baah and McAllister (2012), evaluating methane production in different forages, found that production was higher in grasses, followed by leguminous shrubs, and lowest in nonleguminous shrubs. The response seen in the present study for energy lost through methane production was therefore to be expected, since the smaller the amount of added babassu cake, the higher the levels of Tifton hay in the diet.

Caloric increase (Cl) depends on the amount of food ingested and its composition. In the present study, when measured in kcal $\mathrm{kg}^{-0.75}$ day $^{-1}, \mathrm{Cl}$ was not influenced by the addition of babassu cake $(P>0.05)$. However, when measured as a percentage of GE intake, it showed quadratic behaviour, varying from $9.27 \%$ to $16.10 \%$, for 140 and $350 \mathrm{~g} \mathrm{~kg}^{-1} \mathrm{DM}$ of added babassu cake respectively. As DM intake was not influenced by the diets, other factors in the composition of the feed may have caused the difference in $\mathrm{Cl}$.

The responses for energy loss were consistent with those seen for energy intake (Table 3); it can be concluded from these data that diets with a higher babassu content were energetically more efficient.

The data for metabolisability also showed an increasing linear response $(P<0.05)$ (Table 5), with values ranging from 0.50 to 0.57, similar behaviour, and values close to those reported by Regadas et al. (2011) for diets with a low and medium metabolisable energy content, in sheep fed different levels of metabolisable energy. 
Table 5

Digestible energy (DE), metabolisability $\left(q_{m}\right)$, efficiency of use of metabolisable energy for maintenance $\left(k_{m}\right)$, and the ratio between net energy (NE) and gross energy intake (GEI), in sheep fed babassu cake as a substitute for Tifton- 85 hay

\begin{tabular}{|c|c|c|c|c|c|c|c|c|}
\hline \multirow{2}{*}{ Variable } & \multicolumn{5}{|c|}{ Level of substitution ( $\left.\mathrm{g} \mathrm{kg}^{-1} \mathrm{DM}\right)$} & \multirow{2}{*}{ Equation } & \multirow{2}{*}{$r^{2}$} & \multirow{2}{*}{ CV (\%) } \\
\hline & 70 & 140 & 210 & 280 & 350 & & & \\
\hline $\mathrm{DE}^{1}$ & 59.94 & 59.69 & 62.81 & 61.97 & 63.99 & $\hat{Y}=58.57+0.015 X^{*}$ & 0.79 & 5.08 \\
\hline $\mathrm{q}_{\mathrm{m}}$ & 0.50 & 0.50 & 0.54 & 0.55 & 0.57 & $\hat{Y}=0.48+0.0003 X^{*}$ & 0.92 & 8.62 \\
\hline $\mathrm{k}_{\mathrm{m}}$ & 0.71 & 0.81 & 0.79 & 0.81 & 0.72 & $\hat{Y}=0.59+0.002 X-0.000005 X^{2 *}$ & 0.88 & 12.33 \\
\hline $\mathrm{NE}^{1}$ & 35.48 & 40.54 & 42.00 & 44.35 & 40.69 & $\mathrm{Y}=40.61+3.25^{\mathrm{ns}}$ & - & 16.17 \\
\hline
\end{tabular}

$1 \%$ gross energy intake $(\% \mathrm{GEI}) ;^{*}=\mathrm{P}<0.05 ;^{\mathrm{ns}}=\mathrm{P}>0.05$.

As verified by Regadas et al. (2011), an increase in the fibre concentration of a diet generally results in a reduction in metabolisability, since metabolisability is the relationship between the metabolisable energy and gross energy of the diet, and is therefore directly related to the nutrient concentration. As such, the results corroborate the observations found in the literature, where diets with a higher cake content and, consequently, lower levels of bulk, had a higher $\mathrm{q}_{\mathrm{m}}$.

The values for $\mathrm{k}_{\mathrm{m}}$ showed a quadratic response $(P<0.05)$, varying between 0.71 and 0.81 . The $\mathrm{km}$ expresses the relationship between the net energy and metabolisable energy, therefore, as it is influenced only by the energy lost through $\mathrm{Cl}$, it showed the same behaviour as $\mathrm{Cl}$.

NE values as a percentage of GE intake were not influenced by the diets $(P>0.05)$, varying from $35.48 \%$ to $44.35 \%$, with an average of $40.61 \pm 3.25 \%$; these values were higher than those found by Machado et al. (2015) in the silage of sorghum hybrids, with results ranging from $22.58 \%$ to $40.12 \%$.

In relation to $\mathrm{GE}$, NE values (in \%) can be influenced by the energy lost through faeces, urine, gas fermentation (methane) and Cl (López \& Fernández, 2013). Net energy is therefore related to the energy available for maintaining the animal and and its physical and productive activities, after the digestion, absorption and metabolism of the nutrients.

Daily gas exchange $\left(\mathrm{O}_{2}\right.$ intake, and $\mathrm{CO}_{2}$ and $\mathrm{CH}_{4}$ production) in litres per unit of metabolic size ( $\mathrm{L} \mathrm{kg}^{-0.75}$ ) were not influenced by the diets under evaluation $(P>0.05)$ (Table 6). Oxygen intake varied between 22.64 and 27.21 $\mathrm{L} \mathrm{kg}^{-0.75}$ day $^{-1}$, with an average of $25.24+1.80$ $\mathrm{L} \mathrm{kg}^{-0.75}$ day $^{-1}$. For carbon dioxide production, the values ranged from 22.62 to $25.68 \mathrm{~L} \mathrm{~kg}^{-0.75}$ day $^{-1}$, with an average of $24.29+1.26 \mathrm{~L} \mathrm{~kg}^{-0.75}$ day $^{-1}$. These values are close to those found by Machado et al. (2015) using silage from sorghum hybrids. 
Table 6

Daily oxygen $\left(\mathrm{O}_{2}\right)$ intake, daily carbon dioxide $\left(\mathrm{CO}_{2}\right)$ and methane $\left(\mathrm{CH}_{4}\right)$ production, daily heat production (HP) and respiratory coefficient (RC), in sheep fed babassu cake as a substitute for Tifton-85 hay

\begin{tabular}{|c|c|c|c|c|c|c|c|c|}
\hline \multirow{2}{*}{ Variable } & \multicolumn{5}{|c|}{ Level of substitution ( $\left.\mathrm{g} \mathrm{kg}^{-1} \mathrm{DM}\right)$} & \multirow{2}{*}{ Equation } & \multirow{2}{*}{$r^{2}$} & \multirow{2}{*}{ CV (\%) } \\
\hline & 70 & 140 & 210 & 280 & 350 & & & \\
\hline $\mathrm{O}_{2}{ }^{1}$ & 26.01 & 22.64 & 26.07 & 24.28 & 27.21 & $Y=25.24+1.80^{\text {ns }}$ & - & 25.31 \\
\hline $\mathrm{CO}_{2}{ }^{1}$ & 24.90 & 22.62 & 25.68 & 23.36 & 24.91 & $Y=24.29+1.26^{\text {ns }}$ & - & 24.13 \\
\hline $\mathrm{CH}_{4}{ }^{1}$ & 2.14 & 1.75 & 1.98 & 1.51 & 1.54 & $Y=1.79+0.27^{n s}$ & - & 31.83 \\
\hline $\mathrm{HP}^{2}$ & 122.44 & 108.80 & 119.78 & 116.65 & 130.82 & $Y=119.70+8.05^{\mathrm{ns}}$ & - & 10.04 \\
\hline $\mathrm{RC}$ & 0.96 & 1.00 & 1.00 & 0.97 & 0.92 & $Y=0.97+0.03^{\text {ns }}$ & - & 6.77 \\
\hline
\end{tabular}

${ }^{1}$ Litres per unit of metabolic size $\left(\mathrm{L} \mathrm{kg}^{-0.75}\right)$ per day; ${ }^{2} \mathrm{kcal}$ per unit of metabolic size $\left(\mathrm{kcal} \mathrm{kg}^{-0.75}\right)$ per day; ${ }^{\mathrm{ns}}=\mathrm{P}>0.05$.

For methane production, the variations were from 1.51 to $2.14 \mathrm{~L} \mathrm{~kg}^{-0.75}$ day $^{-1}$, with an average of $1.79+0.27 \mathrm{~L} \mathrm{~kg}^{-0.75}$ day $^{-1}$. These values are higher than those reported by Machado et al. (2015), who found a variation of between 0.99 and $1.36 \mathrm{~L} \mathrm{~kg}^{-0.75}$ day $^{-1}$ using sorghum silage.

Heat production (HP) includes the heat produced as a result of the fermentation processes in the gastrointestinal tract and that released by the intermediate metabolism, representing, on average, 25 to $40 \%$ of the GE intake (NRC, 2007), and is calculated from measurements of the oxygen intake and the production of carbon dioxide and methane, together with the values for nitrogen excreted in the urine (Nielsen, Kiani, Tejada, Chawlibog, \& Alstrup, 2014).

HP values showed no difference between diets $(P>0.05)$, with a mean value of $119.70+8.05 \mathrm{kcal} \mathrm{kg}^{-0.75}$ day $^{-1}$, which is similar to that reported by Gomes et al. (2012), who found an HP of $115.09 \mathrm{kcal} \mathrm{kg}^{-0.75}$ day $^{-1}$ in sheep fed diets based on Tifton-85 hay and concentrate, with a bulk to concentrate ratio of 25:75 (DM basis).

The respiratory coefficient (RC) expresses the ratio between oxygen intake and carbon dioxide production, which take place during the metabolic processes for obtaining energy. The RC reflects the metabolic substrate used, i.e. RC values close to 1.0 would be for carbohydrates, 0.8 for proteins and 0.7 for fats, in addition to reflecting possible differences between species (Nielsen et al., 2014). In the present study, the diets had no influence on the $R C(P>0.05)$, whose values ranged from 0.92 to 1.00 , with an average of $0.97+0.03$, showing that the principal energy substrate of the diets were carbohydrates.

Methane production in litres per day $\left(\mathrm{L}\right.$ day $\left.^{-1}\right)$ and in grams day ${ }^{-1}\left(\mathrm{~g} \mathrm{day}^{-1}\right)$ showed no difference $(P>0.05)$ for the diets under evaluation, with an average of $32.80+5.27 \mathrm{~L}$ day $^{-1}$ and $23.43+3.77 \mathrm{~g}$ day $^{-1}$ respectively (Table 7). Considering the above values, average annual methane production would be $8.43 \mathrm{~kg}$, higher than that reported by Machado et al. (2015) of 3.6 to $5.8 \mathrm{~kg}$ of methane $\mathrm{yr}^{-1}$ in animals fed sorghum silage. According to Knapp et al. (2014), methane production can be influenced by the method of conserving and processing the feed, and tends to be lower in ensiled forages compared to dehydrated forages, which would explain the present result. 


\section{Table 7}

Methane $\left(\mathrm{CH}_{4}\right)$ production in sheep fed babassu cake as a substitute for Tifton-85 hay

\begin{tabular}{|ccccccccc}
\hline \multirow{2}{*}{ Variable } & \multicolumn{9}{c}{ Level of substitution $\left(\mathrm{g} \mathrm{kg}^{-1} \mathrm{DM}\right)$} & \multirow{2}{*}{ Equation } & $\mathrm{r}^{2}$ & $\mathrm{CV}(\%)$ \\
\cline { 2 - 6 } & 70 & 140 & 210 & 280 & 350 & & \\
$\mathrm{CH}_{4}\left(\mathrm{~L} \mathrm{day}^{-1}\right)$ & 40.49 & 33.40 & 33.72 & 26.14 & 30.25 & $\mathrm{Y}=32.80+5.27^{\text {ns }}$ & - & 29.16 \\
$\mathrm{CH}_{4}\left(\mathrm{~g} \mathrm{day}^{-1}\right)$ & 28.92 & 23.85 & 24.09 & 18.67 & 21.60 & $\mathrm{Y}=23.43+3.77^{\text {ns }}$ & - & 29.16 \\
$\mathrm{CH}_{4}\left(\mathrm{~g} \mathrm{~kg}^{-1} \mathrm{DM}\right)$ & 25.00 & 21.78 & 22.57 & 15.61 & 17.15 & $\hat{\mathrm{Y}}=26.99-0.031 \mathrm{X}^{*}$ & 0.78 & 35.61 \\
$\mathrm{CH}_{4}\left(\mathrm{kcal} \mathrm{kg}^{-1} \mathrm{DM}\right)$ & 333.37 & 290.43 & 301.01 & 208.14 & 228.73 & $\hat{\mathrm{Y}}=359.80-0.417 \mathrm{X}^{*}$ & 0.78 & 35.61 \\
\hline
\end{tabular}

${ }^{*}=\mathrm{P}<0.05{ }^{\text {ns }}=\mathrm{P}>0.05$

The data for methane production, in $\mathrm{g}$ $\mathrm{kg}^{-1} \mathrm{DM}$ and in $\mathrm{kcal} \mathrm{kg}^{-1}$ ingested DM, showed similar behaviour, with a decreasing linear response $(P<0.05)$. For every $10 \mathrm{~g} \mathrm{~kg}^{-1} \mathrm{DM}$ of added babassu cake in the diet, there was a reduction of $0.31 \mathrm{~g}$ methane $\mathrm{kg}^{-1}$ ingested DM $(P<0.05)$. These results are to be expected since bulky foods have higher levels of fibrous carbohydrates, where digestion results in a higher proportion of acetate, related to a greater production of methane (Knapp et al., 2014; Ribeiro et al., 2015).

Additionally, the reduction in methane production in animals fed diets with a higher level of added babassu cake can be explained by the increases in the ether extract content of these diets. One of the main effects of lipids in rumen fermentation is a reduction in the digestion of structural carbohydrates, which can reach $50 \%$ or more (Palmquist \& Jenkins, 2017). This can be explained by the possible toxic effect of lipids on rumen microorganisms, particularly fibrolytic bacteria. Furthermore, there are reports of negative effects on methanogenesis, effects that have been attributed to a reduction in methanogenic microbial populations. Methanogenesis can be affected by the rerouting of $\mathrm{H}+$ ions for the biohydrogenation of unsaturated fatty acids, or by an increase in the proportion of propionate, verified by lipid supplementation (Jenkins \& Harvatine, 2014; Palmquist \& Jenkins, 2017).

\section{Conclusions}

The metabolisable energy of babassu cake is 3.26 Mcal kg-1 dry matter, allowing babassu cake to be included in the diet of Santa Inês sheep as a substitute for up to 350 $\mathrm{g} \mathrm{kg}^{-1}$ Tifton-85 hay dry matter, affording an increase in the energy efficiency of the diet. In addition to improving energy efficiency, babassu cake lowers methane production in the animals, contributing to a reduction in greenhouse-gas emissions.

\section{Acknowledgement}

The authors would like to thank Professor Norberto Mario Rodriguez for his guidance during each phase of the research. 


\section{References}

Agricultural and Food Research Council (1993). Energy and requirements of ruminants. Wallingford: $C A B$ International.

Blaxter, K. L., \& Clapperton, J. L. (1965). Prediction of the amount of methane produced by ruminants. British Journal of Nutrition, 19(1), 511-522. doi: 10.1079/ BJN19650046

Carrera, R. A. B., Veloso, C. M., Knupp, L. S., Souza, A. H., Jr., Detmann, E., \& Lana, R. P. (2012). Protein co-products and byproducts of the biodiesel industry for ruminants feeding. Revista Brasileira de Zootecnia, 41(5), 1202-1211. doi: 10.1590/ S1516-35982012000500018

Freitas, M. A. G. D., Siqueira, G. B., \& Siqueira, F. L. T. (2014). Avaliação do uso do resíduo farelo de babaçu (Orbignya sp) na alimentação de ruminantes. Interações (Campo Grande), 15(1), 59-70. doi: 10. 1590/S1518-70122014000100006

Gomes, S. P., Borges, I., Borges, A. L. C. C., Macedo, G. L., Jr., Campos, W. E., \& Brito T. S. (2012). Tamanho de partícula do volumoso e frequência de alimentação sobre o metabolismo energético e protéico em ovinos, considerando dietas com elevada participação de concentrado. Revista Brasileira de Saúde e Produção Animal, 13(3), 732-744. doi: 10.1590/S1519-99402012000300013

Grainger, C., \& Beauchemin, K. A. (2011). Can enteric methane emissions from ruminants be lowered without lowering their production? Animal Feed Science and Technology, 166 (Special Issue), 308-320. doi: 10.1016/j.anifeedsci.2011.04.021
Jenkins, T. C., \& Harvatine, K. J. (2014). Lipid feeding and milk fat depression. Veterinary Clinics of North America: Food Animal Practice, 30(3), 623-642. doi: 10.1016/j. cvfa.2014.07.006

Knapp, J. R., Laur, G. L., Vadas, P. A., Weiss, W. P., \& Tricarico, J. M. (2014). Invited review: enteric methane in dairy cattle production: Quantifying the opportunities and impact of reducing emissions. Journal of Dairy Science, 97(6), 3231-3261. doi: 10.3168/ jds.2013-7234

López, M. C., \& Fernández, C. (2013). Energy partitioning and substrate oxidation by Murciano-Granadina goats during mid lactation fed soy hulls and corn gluten feed blend as a replacement for corn grain. Journal of Dairy Science, 96(7), 4542-4552. doi: 10.3168/jds.2012-6473

Machado, F. S., Rodriguez, N. M., Gonçalves, L. C., Rodrigues, J. A. S., Ribas, M. N., Pôssas, F. P.,... Tomich, T. R. (2015). Energy partitioning and methane emission by sheep fed sorghum silages at different maturation stages. Arquivo Brasileiro de Medicina Veterinária e Zootecnia, 67(3), 790-800. doi: 10.1590/1678-4162-7177

Meale, S. J., Chaves, A. V., Baah, J., \& McAllister, T. A. (2012). Methane production of different forages in in vitro ruminal fermentation. Asian-Australasian Journal of Animal Sciences, 25(1), 86-91. doi: 10.5713/ajas.2011.11249

Miotto, F. R. C., Restle, J., Neiva, J. N. M., Maciel, R. P., \& Fernandes, J. R. (2012). Consumo e digestibilidade de dietas contend níveis de farelo do mesocarpo de babaçu para ovinos. Revista Ciência Agronômica, 43(4), 792-801. doi: 10.1590/S1806-6690 2012000400022 
National Research Council (2007). Nutrient requirements of small ruminants: sheep, goats, cervids, and new world camelids. Washington, DC: National Academy Press.

Nielsen, M. O., Kiani, A., Tejada, E., Chawlibog, A., \& Alstrup, L. (2014). Energy metabolism and methane production in llamas, sheep and goats fed high-and lowquality grass-based diets. Archives of Animal Nutrition, 68(3), 171-185. doi: 10. 1080/1745039X.2014.912039

Palmquist, D. L., \& Jenkins, T. C. (2017). A 100year review: fat feeding of dairy cows. Journal of Dairy Science, 100(12), 1006110077. doi: 10.3168/jds.2017-12924

Regadas, J. G. L., Fo., Pereira, E. S., Villarroel, A. B. S., Pimentel, P. G., Fontenele, R. M., Costa, M. R. G.,... Sombra, W. A. (2011). Efficiency of metabolizable energy utilization for maintenance and gain and evaluation of Small Ruminant Nutrition System model in Santa Ines sheep. Revista Brasileira de Zootecnia, 40(11), 2558-2564. doi: 10. 1590/S1516-35982011001100038

Ribeiro, G. O., Jr., Teixeira, A. M., Velasco, F. O., Faria, W. G., Jr., Jayme, D. G., Maurício, R. M.,... McAllister, T. A. (2015). Methane production and energy partitioning in sheep fed Andropogon gayanus grass ensiled at three regrowth stages. Canadian Journal of Animal Science, 95(1), 103-110. doi: 10.4141/CJAS-2014-074

Rodriguez, N. M., Campos, W. E., Lachica, M. L., Borges, I., Gonçalves, L. C., Borges, A. L. C. C., \& Saliba, E. O. S. (2007). A calorimetry system for metabolism trials. Arquivo Brasileiro de Medicina Veterinária e Zootecnia, 59(2), 495-500. doi: 10.1590/ S0102-09352007000200033

Silva, D. J., \& Queiroz, A. C. (2002). Análise de alimentos: métodos químicos e biológicos (3a ed.). Viçosa, MG: UFV.

Sniffen, C. J., O'Connor, D. J., Van Soest, P. J., Fox, D. G., \& Russell, J. B. (1992). A net carbohydrate and protein system for evaluating cattle diets: carbohydrate and protein availability. Journal of Animal Science, 70(11), 3562-3577. doi: 10.25 27/1992.70113562x

Tangjitwattanachai, N., Phaowphaisal, M. O., \& Sommart, K. (2015). Enteric methane emission, energetic efficiency and energy requirements for the maintenance of beef cattle in the tropics. Japan Agricultural Research Quarterly, 49(4), 399-407. doi: 10.6090/jarq.49.399 